\title{
Electro-deposition and re-oxidation of carbon in carbonate-containing molten salts
}

\author{
Happiness V. Ijije, Richard C. Lawrence, Nancy J. Siambun, $\uparrow$ \\ Sang Mun Jeong, $\$$ Daniel A. Jewell,§ Di Hu and George Z. Chen*
}

Received 21st March 2014, Accepted 6th May 2014

DOI: $10.1039 / c 4 f d 00046 c$

The electrochemical deposition and re-oxidation of solid carbon were studied in $\mathrm{CO}_{3}{ }^{2-}$ ion-containing molten salts (e.g. $\mathrm{CaCl}_{2}-\mathrm{CaCO}_{3}-\mathrm{LiCl}-\mathrm{KCl}$ and $\mathrm{Li}_{2} \mathrm{CO}_{3}-\mathrm{K}_{2} \mathrm{CO}_{3}$ ) at temperatures between 500 and $800{ }^{\circ} \mathrm{C}$ under $\mathrm{Ar}, \mathrm{CO}_{2}$ or $\mathrm{N}_{2}-\mathrm{CO}_{2}$ atmospheres. The electrode reactions were investigated by thermodynamic analysis, cyclic voltammetry and chronopotentiometry in a three-electrode cell under various conditions. The findings suggest that the electro-reduction of $\mathrm{CO}_{3}{ }^{2-}$ is dominated by carbon deposition on all three tested working electrodes ( $\mathrm{Ni}, \mathrm{Pt}$ and mild steel), but partial reduction to $\mathrm{CO}$ can also occur. Electro-re-oxidation of the deposited carbon in the same molten salts was investigated for potential applications in, for example, direct carbon fuel cells. A brief energy and cost analysis is given based on results from constant voltage electrolysis in a two-electrode cell.

\section{Introduction}

Electrochemical reduction of the carbonate ion $\left(\mathrm{CO}_{3}{ }^{2-}\right)$ to solid carbon in molten salts has been known to be possible since the mid-1960s. ${ }^{1,2}$ It then gained only a limited interest, ${ }^{3,4}$ possibly because of the ready availability of various forms of carbon from fossil resources and biomass. However, in recent years renewed interest has grown fairly fast, ${ }^{5-11}$ due largely to the need to reduce $\mathrm{CO}_{2}$ emissions to avoid detrimental climate change, and, more importantly, to utilise this waste gas as a carbon source for the synthesis and processing of materials and chemicals, such as steel carburisation and the production of so called solar fuels. ${ }^{\mathbf{8}, 12}$ In

Department of Chemical and Environmental Engineering, and Energy and Sustainability Research Division, Faculty of Engineering, University of Nottingham, University Park, Nottingham NG7 2RD, UK. E-mail: george.chen@nottingham.ac.uk

$\dagger$ Current address: School of Engineering and Information Technology, Universiti Malaysia Sabah, 88999 Kota Kinabalu, Sabah, Malaysia.

\$ Current address: Department of Chemical Engineering, Chungbuk National University, 410 Seongbongno, Heungduk-gu, Cheongju-si, Chungcheongbuk-do, 361-763, Republic of Korea.

$\S$ Current address: Coogee Titanium, Unit 4/25, Agosta Drive, Laverton North, VIC Australia 3026. 
fact, solar fuel production can be regarded as an energy storage process that is very suitable for remote and seasonal purposes. Yet, considering its high energy content, carbon production from $\mathrm{CO}_{2}$ is far better for energy storage $\left(\Delta H^{\mathrm{o}}=\right.$ $-25.97 \mathrm{MJ} \mathrm{L}^{-1}$ at $20{ }^{\circ} \mathrm{C}$ for a carbon powder packed to $0.792 \mathrm{~g} \mathrm{~mL}^{-1}$ in apparent density) in comparison with, for example, methanol production from $\mathrm{CO}_{2}$ and $\mathrm{H}_{2} \mathrm{O}\left(\Delta H^{\mathrm{o}}=-16.71 \mathrm{MJ} \mathrm{L}^{-1}\right.$ at $20{ }^{\circ} \mathrm{C}$ for liquid $\mathrm{CH}_{3} \mathrm{OH}$ of $0.792 \mathrm{~g} \mathrm{~mL}^{-1}$ in density). ${ }^{13}$ This simple thermodynamic comparison has formed the basis of our research programme since $2006 .{ }^{14}$ Herein we summarise our findings on the electro-deposition of solid carbon from molten salts under $\mathrm{CO}_{2}$ containing atmospheres, ${ }^{\mathbf{8}, 11}$ and report for the first time our investigation on the electrochemical oxidation of electro-deposited carbon in molten salts.

The molten salt suitable for the electrolytic production of carbon from $\mathrm{CO}_{2}$ should be able to dissolve the $\mathrm{O}^{2-}$ ion which is a product of carbon deposition, and also helps to absorb $\mathrm{CO}_{2}$ and convert it to the $\mathrm{CO}_{3}{ }^{2-}$ ion. Because of their low costs and environmental impacts, both chloride and carbonate salts, and in particular their mixtures, were investigated in this laboratory. ${ }^{\mathbf{8 , 1 1}}$ It has been observed that electro-deposition of carbon can proceed in all tested molten salt combinations, as long as $\mathrm{Li}^{+}$ions are present. ${ }^{1-4}$ In other cases, deposition is not impossible, but occurs at much lower rates. ${ }^{15}$ This phenomenon may be accounted for by the relative deposition potential of $\mathrm{Li}$, Na, or $\mathrm{K}$ metal compared with that of carbon, as expressed by the following reactions:

$$
\begin{gathered}
2 \mathrm{M}_{2} \mathrm{CO}_{3}=4 \mathrm{M}+2 \mathrm{CO}_{2}+\mathrm{O}_{2}(\mathrm{M}=\mathrm{Li}, \mathrm{Na} \text { or } \mathrm{K}) \\
3 \mathrm{M}_{2} \mathrm{CO}_{3}=\mathrm{C}+3 \mathrm{M}_{2} \mathrm{O}+2 \mathrm{CO}_{2}+\mathrm{O}_{2}
\end{gathered}
$$

Note that reaction (2) is actually the sum of the following reactions (3) and (4) $\times 2$ :

$$
\begin{gathered}
\mathrm{M}_{2} \mathrm{CO}_{3}=\mathrm{C}+\mathrm{M}_{2} \mathrm{O}+\mathrm{O}_{2} \\
\mathrm{M}_{2} \mathrm{CO}_{3}=\mathrm{M}_{2} \mathrm{O}+\mathrm{CO}_{2}
\end{gathered}
$$

This combination aids electrochemical analysis, since both reactions (1) and (2) have the same anodic reaction (5) below:

$$
2 \mathrm{CO}_{3}{ }^{2-}=2 \mathrm{CO}_{2}+\mathrm{O}_{2}+4 \mathrm{e}\left(E^{\mathrm{o}}=0 \mathrm{~V}\right)
$$

The potentials of reactions (1) and (2) against reaction (5), i.e. a hypothetical reference electrode of $\mathrm{CO}_{3}{ }^{2-} / \mathrm{CO}_{2}-\mathrm{O}_{2}$, are listed in Table $1^{13}$ which shows that in

Table 1 Deposition potentials ( $\mathrm{vs} . \mathrm{CO}_{3}{ }^{2-} / \mathrm{CO}_{2}-\mathrm{O}_{2}$ ) of alkali and alkaline earth metals via reaction (1), and carbon via reaction (2) in their own molten carbonate salts at $600{ }^{\circ} \mathrm{C}$

\begin{tabular}{llc}
\hline Molten salt & Alkali metal & Carbon \\
\hline $\mathrm{Li}_{2} \mathrm{CO}_{3}$ & $-2.964 \mathrm{~V}$ & $-1.719 \mathrm{~V}$ \\
$\mathrm{Na}_{2} \mathrm{CO}_{3}$ & $-2.546 \mathrm{~V}$ & $-2.551 \mathrm{~V}$ \\
$\mathrm{~K}_{2} \mathrm{CO}_{3}$ & $-2.612 \mathrm{~V}$ & $-3.083 \mathrm{~V}$ \\
$\mathrm{CaCO}_{3}$ & $-3.033 \mathrm{~V}$ & $-1.349 \mathrm{~V}$ \\
$\mathrm{BaCO}_{3}$ & $-3.069 \mathrm{~V}$ & $-1.992 \mathrm{~V}$
\end{tabular}


molten alkali carbonates, carbon deposition is thermodynamically preferred to $\mathrm{Li}$ deposition, but more difficult than $\mathrm{Na}$ or $\mathrm{K}$ deposition, which is in line with experimental observations of the authors and others. ${ }^{\mathbf{1 - 4 , 1 5}}$ (With reference to $\mathrm{CO}_{3}{ }^{2-} / \mathrm{CO}_{2}-\mathrm{O}_{2}$, in the following discussion, the standard potential, $E^{\mathrm{o}}$, provided next to the electrode reaction, is for the reaction occurring in pure molten $\mathrm{Li}_{2} \mathrm{CO}_{3}$ at $600{ }^{\circ} \mathrm{C}$.)

Previous studies of the electro-deposition of carbon were mostly carried out in molten alkali metal salts. However, thermodynamic calculations show that it also possible to use molten alkaline earth metal salts. It can be seen in Table 1 that carbon deposition is also preferred to alkaline earth metal deposition in both molten $\mathrm{CaCO}_{3}$ and $\mathrm{BaCO}_{3}$. However, $\mathrm{CaCO}_{3}$ decomposes at temperatures only slightly above its melting point $\left(825^{\circ} \mathrm{C}\right) . \mathrm{MgCO}_{3}$ is even worse and decomposes at temperatures below $350{ }^{\circ} \mathrm{C}$ before melting, which is the reason why Table 1 does not contain data for $\mathrm{MgCO}_{3} \cdot \mathrm{BaCO}_{3}$ is thermally more stable but it is expensive to use, whilst barium salt toxicity is also a concern. Nevertheless, in this work, it was found that electro-deposition of carbon could be achieved in the molten mixture of $\mathrm{CaCl}_{2}$ and $\mathrm{CaCO}_{3}$ (84:16 in a molar ratio) at temperatures higher than $730{ }^{\circ} \mathrm{C}$. To lower the working temperature, mixtures of chlorides were used in some cases to dissolve $\mathrm{CaCO}_{3}$ and enable electro-deposition of carbon.

\section{Experimental}

Details of chemicals, materials, experimental equipment, set up and procedures can either be found in previous publications from this laboratory, ${ }^{\mathbf{8}, 11,17}$ or are specified in this paper.

\section{Results and discussion}

Fig. 1a presents the cyclic voltammogram (CV) of a Ni wire working electrode in the quaternary mixture of $0.30 \mathrm{CaCl}_{2}-0.17 \mathrm{CaCO}_{3}-0.43 \mathrm{LiCl}-0.10 \mathrm{KCl}$ in a molar ratio. The $\mathrm{CV}$ was recorded under argon, instead of $\mathrm{CO}_{2}$, so that if carbon deposition does occur, it can be attributed without doubt to the reduction of the $\mathrm{CO}_{3}{ }^{2-}$ ion. The most prominent feature of the CV in Fig. 1a is an almost symmetrical and large reduction current peak $\mathrm{C} 1$. To confirm carbon deposition, the Ni wire working electrode was removed from the molten salt bath after recording two consecutive CVs similar to that in Fig. 1a. A carbon coating was clearly seen on the $\mathrm{Ni}$ wire as evidenced by the photograph in Fig. 1b. According to Table 1, peak C1 can be attributed to carbon deposition because its potential was less negative than those of the other two reduction peaks (C2 and C3). The potentials of C2 and $\mathrm{C} 3$ relative to that of $\mathrm{C} 1$ suggest $\mathrm{K}$ and Li deposition, respectively. Deposition of $\mathrm{Ca}$ requires a more negative potential and hence did not appear on the CV.

To enhance the carbon deposition, electrolysis was carried out in a two electrode cell under different $\mathrm{CO}_{2}$ partial pressures. The cathode was a mild steel rod of $5.0 \mathrm{~mm}$ dia., and the anode was a $\mathrm{SnO}_{2}$ rod of $10.0 \mathrm{~mm}$ dia. which functioned as an inert anode. ${ }^{16} \mathrm{~A}$ high cell voltage $(4.0 \mathrm{~V})$ was applied to gain a high deposition rate. The molten salt bath temperature was also increased to $579{ }^{\circ} \mathrm{C}$ for the same reason. The electrolysis current was observed to increase with the $\mathrm{CO}_{2}$ partial pressure as exemplified in Fig. 2a, in agreement with the reduction (6) and regeneration (7) of $\mathrm{CO}_{3}{ }^{2-}$ ions as follows: 

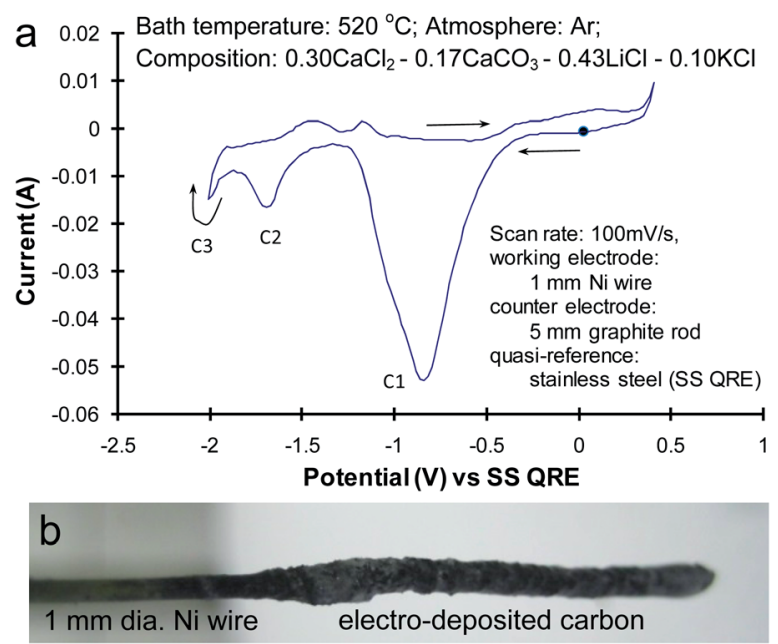

Fig. 1 (a) The cyclic voltammogram (CV) of a nickel wire in a quaternary molten salt bath. Experimental conditions are indicated with the bath composition in a molar ratio. The potential scan started cathodically from $0 \mathrm{~V}$ as indicated by the round solid spot on the CV. (b) A photograph showing the Ni wire working electrode $(1 \mathrm{~mm}$ dia.) with deposited carbon after recording two consecutive CVs.

$$
\begin{gathered}
\mathrm{CO}_{3}{ }^{2-}+4 \mathrm{e}=\mathrm{C}+3 \mathrm{O}^{2-}\left(\mathrm{C} 1, E^{\mathrm{o}}=-1.719 \mathrm{~V}\right) \\
\mathrm{CO}_{2}+\mathrm{O}^{2-}=\mathrm{CO}_{3}{ }^{2-}
\end{gathered}
$$

Note that the bath compositions differ slightly in Fig. 1a and 2a, which was not intentional, but was due to the inconvenience of preparing the multicomponent molten salt bath. To compare the results, electrolysis was terminated at $1 \mathrm{~h}$, and the cathode was removed from the bath. Fig. 2b displays a photograph of the cathodes, showing an increasing thickness of the deposited carbon coating with increasing $\mathrm{CO}_{2}$ partial pressure.

It is interesting to note in Fig. $2 \mathrm{~b}$ that the surface of the deposited carbon was covered by small craters that were strong evidence of gas bubbles being formed on the cathode during electrolysis. This was thought to be $\mathrm{CO}$ formation via reaction (8). If not escaping from the molten salt, CO may undergo further changes on the electrode via reactions (9) and/or (10):

$$
\begin{gathered}
\mathrm{CO}_{3}^{2-}+2 \mathrm{e}=\mathrm{CO}+2 \mathrm{O}^{2-}\left(E^{\mathrm{o}}=-0.947 \mathrm{~V}, \mathrm{~A} 2\right) \\
\mathrm{CO}+2 \mathrm{e}=\mathrm{C}+\mathrm{O}^{2-}\left(E^{\mathrm{o}}=-1.442 \mathrm{~V}, \mathrm{Al}^{\prime}\right) \\
2 \mathrm{CO}+\mathrm{O}^{2-}=\mathrm{CO}_{3}{ }^{2-}+\mathrm{C}
\end{gathered}
$$

Note that $(10)=(9)-(8)$, and it is a chemical reaction. However, the observed small craters in Fig. 2b seem to indicate slower kinetics of reactions (9) and (10), likely because $\mathrm{CO}$ was in the gas phase. Also, reactions (8) and (10) suggest that the $\mathrm{O}^{2-}$ ions could prevent or reduce the formation of CO bubbles, which agrees 

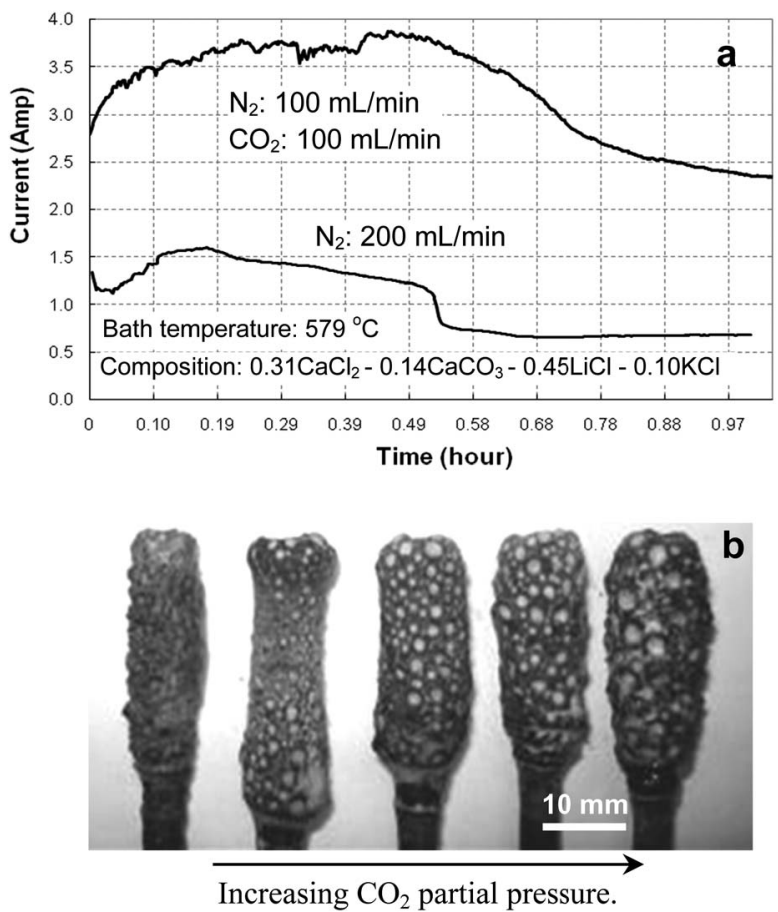

Fig. 2 (a) Current-time plots recorded during constant voltage (4.0 V) electrolysis in a quaternary molten salt bath with a mild steel cathode $\left(5 \mathrm{~mm}\right.$ dia. rod) and $\mathrm{SnO}_{2}$ anode (10 $\mathrm{mm}$ dia. rod) under different atmospheres as indicated. (b) The mild steel rod cathodes with carbon deposits collected after $1 \mathrm{~h}$ of electrolysis. The electro-deposition on each cathode was carried out consecutively in the same bath, but under different ratios of $\mathrm{N}_{2}$ and $\mathrm{CO}_{2}$ flow rates ( $\mathrm{mL} \mathrm{min}^{-1}$, from left to right): $200: 0$ (pure $\mathrm{N}_{2}$ ); $150: 50,100: 100$, $50: 150$ and $0: 200$ (pure $\mathrm{CO}_{2}$ ). The total pressure in the electrolyser was $1 \mathrm{~atm}$.

with the absence of craters on the carbon coatings deposited from carbonate dominated baths, as discussed below.

The fairly symmetrical shape of peak $\mathrm{C} 1$ in Fig. 1a implies that Ni may have some catalytic effect on $\mathrm{CO}_{3}{ }^{2-}$ reduction. It was also observed that the current of the symmetrical peak $\mathrm{C} 1$ decreased significantly on the $2^{\text {nd }}$ potential cycle, which may result from the Ni surface being covered by the deposited carbon and hence losing its catalytic effect. On the other hand, the absence of a re-oxidation counterpart of peak $\mathrm{C} 1$ suggests the irreversibility of the carbon deposition in the chloride dominated molten salt bath. This could be related to the $\mathrm{CV}$ being recorded under $\mathrm{Ar}$, and that there were too few $\mathrm{O}^{2-}$ and/or $\mathrm{CO}_{3}{ }^{2-}$ ions in the chloride dominated molten salt bath to assist carbon oxidation via reaction (11) or (12) below: ${ }^{6}$

$$
\begin{gathered}
\mathrm{C}+2 \mathrm{O}^{2-}=\mathrm{CO}_{2}+4 \mathrm{e}\left(\mathrm{A} 1, E^{\mathrm{o}}=-1.488 \mathrm{~V}\right) \\
\mathrm{C}+2 \mathrm{CO}_{3}{ }^{2-}=3 \mathrm{CO}_{2}+4 \mathrm{e}\left(\mathrm{A} 3, E^{\mathrm{o}}=-1.025 \mathrm{~V}\right)
\end{gathered}
$$

It was then thought that if the CVs were recorded in a carbonate dominated molten salt bath under $\mathrm{CO}_{2}$, carbon deposition and re-oxidation of the deposited 
carbon could both be facilitated. To confirm this, the molten eutectic mixture of $\mathrm{Li}_{2} \mathrm{CO}_{3}-\mathrm{K}_{2} \mathrm{CO}_{3}$ (molar ratio: $62: 38$ ) was used to record CVs. ${ }^{11}$ Note that the Ni wire was replaced by a $\mathrm{Pt}$ wire which can offer a greater stability at more positive potentials to allow studies of all possible anodic reactions. Also, an alumina membrane $\mathrm{Ag} / \mathrm{AgCl}$ reference electrode was used to offer a more stable reference potential. ${ }^{16}$

Typical CVs obtained in $\mathrm{Li}_{2} \mathrm{CO}_{3}-\mathrm{K}_{2} \mathrm{CO}_{3}$ are presented in Fig. 3. The potential window is about $1.90 \mathrm{~V}$ between the current onset potentials of peaks $\mathrm{C} 1(-1.65 \mathrm{~V}$ vs. $\mathrm{Ag} / \mathrm{AgCl})$ and $\mathrm{A} 4(0.25 \mathrm{~V} v$ s. $\mathrm{Ag} / \mathrm{AgCl})$ measured in Fig. 3a. This is slightly wider than that of pure $\mathrm{Li}_{2} \mathrm{CO}_{3}(1.72 \mathrm{~V}$, Table 1$)$, but it is understandable considering the influence of $\mathrm{K}_{2} \mathrm{CO}_{3}$. The CVs present a significant reduction peak $\mathrm{C} 1$, and several re-oxidation peaks as highlighted in Fig. 3b. To confirm that these anodic peaks are indeed due to re-oxidation of the deposited carbon, the potential was held at the cathodic limit $(-2.0 \mathrm{~V})$ for $10 \mathrm{~s}$ before the scan was reversed. In response, all anodic peaks increased significantly in current, whilst peak $\mathrm{A}^{\prime}$ was engulfed in
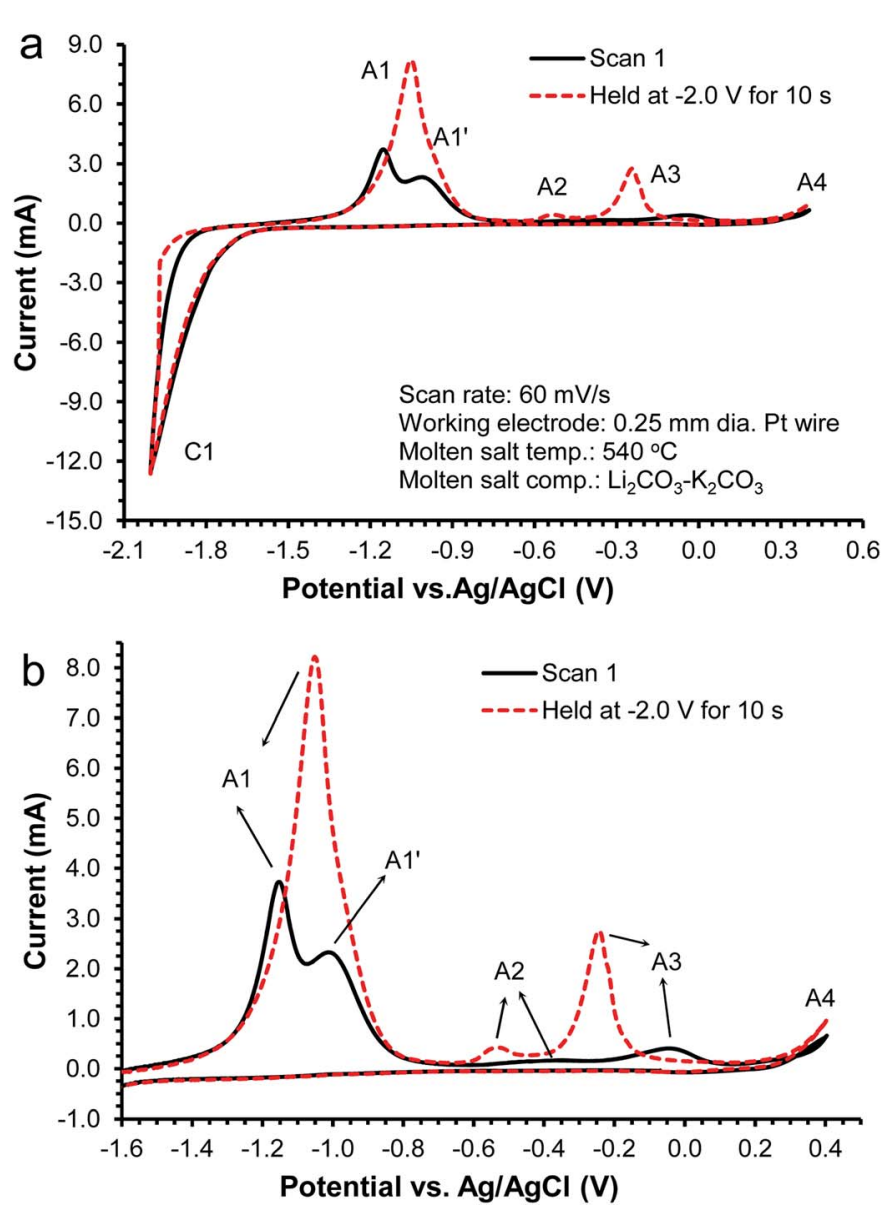

Fig. $3 \mathrm{CVs}$ of a Pt wire $\left(0.25 \mathrm{~mm}\right.$ dia.) in molten $\mathrm{Li}_{2} \mathrm{CO}_{3}-\mathrm{K}_{2} \mathrm{CO}_{3}$ (62: 38 molar ratio) at $540^{\circ} \mathrm{C}$; scan rate: $100 \mathrm{mV} \mathrm{s}^{-1}$. (a) Full potential range. (b) Enlargement of the anodic branches of the CVs in (a). 
A1. This phenomenon can be explained as follows: more carbon was deposited when the potential was held at $-2.0 \mathrm{~V}$ and hence contributed to greater reoxidation currents. According to their relative potentials, peaks A1 and A3 can be attributed to reactions (11) and (12), respectively. Peaks A1' and A2 were likely the reversals of reactions (9) and (8), respectively, considering their potentials relative to that of A1 for reaction (11). Interestingly, both peaks A2 and A3 shifted negatively after holding the potential scan at $-2.0 \mathrm{~V}$ for $10 \mathrm{~s}$. It is very likely that when $\mathrm{CO}$ is produced after peak A1' via the reverse of reaction (9), it adsorbs on the carbon surface, impeding reaction (12) and hence there is a more positive potential for peak $\mathrm{A} 3$. Thus, the absence of $\mathrm{A}^{\prime}{ }^{\prime}$ on the $\mathrm{CV}$ after holding the potential at $-2.0 \mathrm{~V}$ means a lowered influence of $\mathrm{CO}$, and hence the negative shift of $\mathrm{A} 3$. If peak $\mathrm{A} 2$ corresponds to the reverse of reaction (8), its negative shift may result from a smaller number and size of the $\mathrm{CO}$ nuclei on the deposited carbon.

The oxidation current, A4, at the anodic potential limit $(0.5 \mathrm{~V})$ may be attributed to the discharge of either the $\mathrm{O}^{2-}$ ion to form $\mathrm{O}_{2}(13)$, or of the $\mathrm{CO}_{3}{ }^{2-}$ ion to form $\mathrm{O}_{2}$ and $\mathrm{CO}_{2}(5)$.

$$
2 \mathrm{O}^{2-}=\mathrm{O}_{2}+4 \mathrm{e}\left(E^{\mathrm{o}}=-0.463 \mathrm{~V}\right)
$$

If reaction (13) had occurred, its current should have appeared at potentials between A3 and A4 on the CV. However, for reaction (13) to proceed, a significant amount of $\mathrm{O}^{2-}$ ions should be present near the electrode. This was unlikely to be the case, considering that the $\mathrm{O}^{2-}$ ions, including those already present in the molten carbonate salts and those produced during carbon deposition via reaction (6), should have mostly been consumed in the course of the potential scan from A1 to A3. Thus, A4 should correspond to reaction (5).

Having obtained a basic understanding of the CV, further analysis was carried out to study the feasibility of employing the carbon deposition and dissolution processes for electrochemical energy storage and reuse. This effort started in this work by comparing the charges passed during the cathodic and anodic potential scans when recording the CVs. Some of the results obtained are listed in Table 2.

As it can be seen in Table 2 , the $Q^{+} / Q^{-}$ratio increased with a decreasing potential scan rate. In line with this trend, it was found that holding the potential for $10 \mathrm{~s}$ at the cathodic end could further increase the $Q^{+} / Q^{-}$ratio to close to 1. These observations imply that carbon deposition may not proceed well on the

Table 2 The ratios of anodic $\left(Q^{+}\right)$and cathodic $\left(Q^{-}\right)$charges measured from CVs (cf. Fig. 3) as a function of potential scan rate ${ }^{a}$

\begin{tabular}{lccc}
\hline Scan rate $\left(\mathrm{mV} \mathrm{s}^{-1}\right)$ & $Q^{-}(\mathrm{C})$ & $Q^{+}(\mathrm{C})$ & $Q^{+} / Q^{-}$ \\
\hline 100 & 3.575 & 1.776 & 0.50 \\
80 & 6.220 & 3.151 & 0.51 \\
60 & 6.524 & 3.362 & 0.52 \\
40 & 10.75 & 5.737 & 0.53 \\
20 & 25.56 & 14.41 & 0.56 \\
10 & 73.56 & 47.70 & 0.65
\end{tabular}

${ }^{a}$ Note: all measurements were made using a fresh Pt working electrode in the same molten salt bath. 
fresh Pt electrode, but becomes more efficient (although not necessarily quicker) after the Pt electrode is covered by the deposited carbon. In other words, carbon deposition on the Pt surface may proceed in competition with other reactions whose products do not remain on the electrode (e.g. CO formation), but these side reactions encounter higher kinetic barriers on the carbon surface. This understanding is practically important because it basically means that for the electrodeposition of carbon, the cathode material can be any metal or alloy as long as it is cathodically stable in the molten salt.

To further study the electro-oxidation of the deposited carbon, potentiostatic control was applied to produce a sufficient amount of carbon deposit for further analyses. In particular, chronopotentiometry was carried out to confirm reactions (11) and (12) as the main anodic reactions on the deposited carbon. In these experiments, the working electrode was a $5 \mathrm{~mm}$ dia. mild steel rod, whilst graphite, $\mathrm{SnO}_{2}$ and stainless steel were all tested as the counter electrode material, and similar results were obtained. However, stainless steel was proven to be the most convenient choice for various carbonate dominated baths, although minor anode dissolution and consequent contamination of the deposited carbon were observed. ${ }^{11}$ Thus, the following discussion will focus on data obtained from using the stainless steel counter electrode.

Fig. 4 compares the chronopotentiometric plots recorded during anodic oxidation (dissolution or galvanostatic discharge) of the electro-deposited carbon obtained under potentiostatic control. Both pure $\mathrm{Li}_{2} \mathrm{CO}_{3}$ and $\mathrm{Li}_{2} \mathrm{CO}_{3}-\mathrm{K}_{2} \mathrm{CO}_{3}$ were tested for comparison. On all plots in Fig. 4, there are two clearly distinguishable plateaux at potentials corresponding approximately to those of reactions (11) and (12). In Fig. $4 \mathrm{~b}$ and c, a third potential plateau is shown at a more positive potential. The potential difference between the lowest and highest plateaux is about $1.75 \mathrm{~V}$ which can be explained by polarisations in addition to the theoretical value of $1.488 \mathrm{~V}$ between reactions (5) and (11). Polarisation is evident from a comparison between Fig. $4 \mathrm{a}$ and $\mathrm{b}$. The potential difference between the first and second plateaux is about $0.40 \mathrm{~V}$ in Fig. $4 \mathrm{a}$, but it increases to about $0.78 \mathrm{~V}$ in Fig. 4 b. The larger current and lower temperature for recording Fig. 4 b would have contributed to increasing both the ohmic and charge transfer polarisations. Thus, the third plateau can be attributed to reaction (5), i.e. electro-oxidation of the $\mathrm{CO}_{3}{ }^{2-}$ ion.

Similar to the CVs in Fig. 3 which indicate no clear presence of direct anodic discharge of the $\mathrm{O}^{2-}$ ion, i.e. reaction (13), the plots in Fig. 4 also show only a barely visible inflexion of the rapidly increasing current between the $2^{\text {nd }}$ and $3^{\text {rd }}$ plateaux. This is understandable because the $\mathrm{O}^{2-}$ activity must be significantly lower than that of the $\mathrm{CO}_{3}{ }^{2-}$ ion in the molten carbonate salts used. Also, these experiments were carried out under $\mathrm{CO}_{2}$ which could also help convert $\mathrm{O}^{2-}$ to $\mathrm{CO}_{3}{ }^{2-}$.

For energy storage, a high $Q^{+} / Q^{-}$ratio approaching 1 is desirable. Cyclic voltammetry has revealed promising results as shown in Table 2 . More analyses were carried out on carbon coatings deposited under potentiostatic control and discharged (re-oxidised) via chronopotentiometry. Some of the preliminary findings are presented in Table 3.

The $Q^{+} / Q^{-}$ratio was found to be a complex function of both deposition and reoxidation variables. The deposition potential (and voltage if in a two-electrode cell) plays the most significant role. With an increasingly negative deposition 

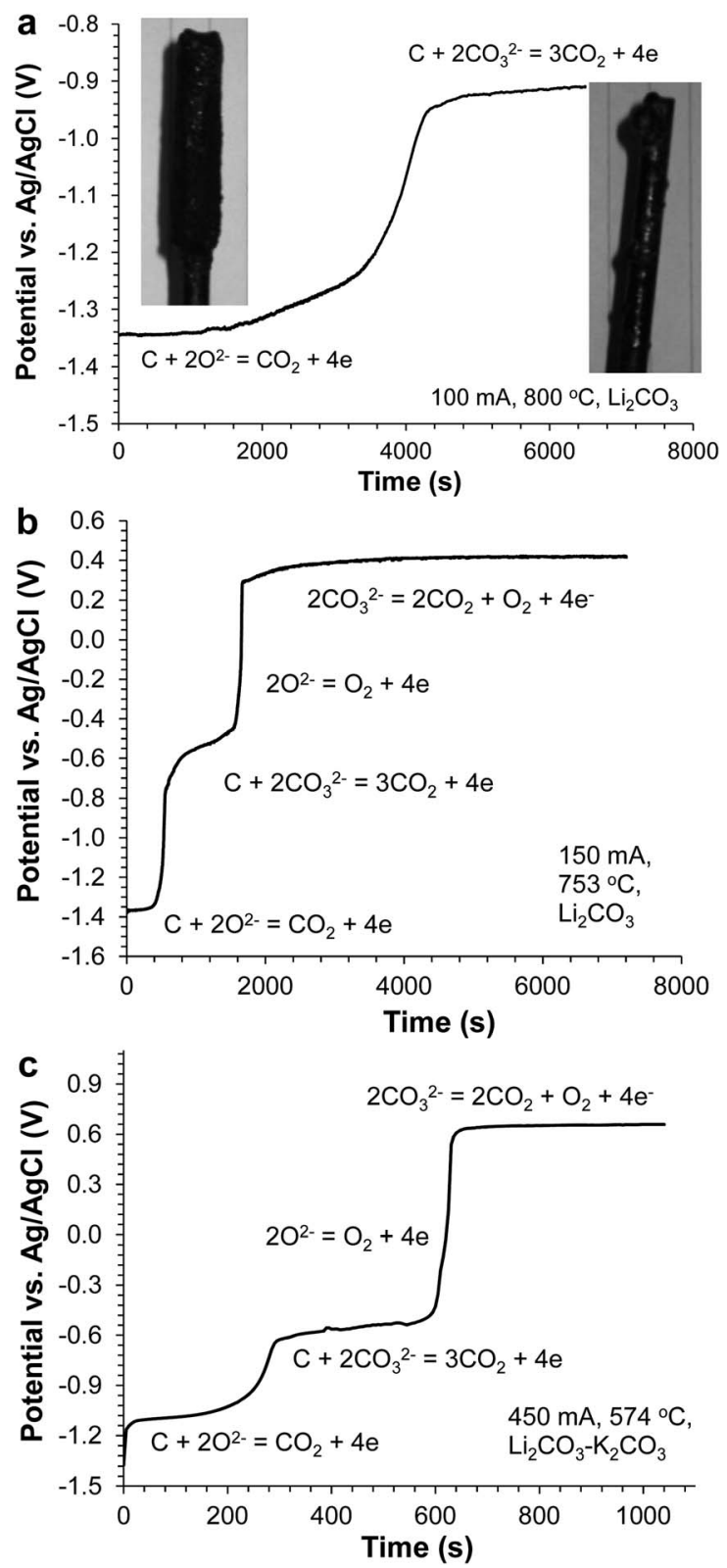

Fig. 4 Chronopotentiometric plots for anodic oxidation of the electro-deposited carbon in the same molten salt under $\mathrm{CO}_{2}$. (a) $\mathrm{Li}_{2} \mathrm{CO}_{3}$ at $800{ }^{\circ} \mathrm{C}$, oxidation: $100 \mathrm{~mA}$, deposition: $-1.8 \mathrm{~V}$ vs. $\mathrm{Ag} / \mathrm{AgCl}, 3600 \mathrm{~s}$. (b) $\mathrm{Li}_{2} \mathrm{CO}_{3}$ at $753^{\circ} \mathrm{C}$, oxidation: $150 \mathrm{~mA}$, deposition: $-2.1 \mathrm{~V}$ for 600 s. (c) $\mathrm{Li}_{2} \mathrm{CO}_{3}-\mathrm{K}_{2} \mathrm{CO}_{3}$ (molar ratio: 62 : 38) at $574{ }^{\circ} \mathrm{C}$, oxidation: $450 \mathrm{~mA}$, deposition: $-2.6 \mathrm{~V}$ for $600 \mathrm{~s}$. The photographs in (a) show the working electrode $(5 \mathrm{~mm}$ dia. mild steel rod) with the carbon deposit (left), and after anodic oxidation (right). Counter electrode: $10 \mathrm{~mm}$ diameter graphite rod. 
potential, the $Q^{+} / Q^{-}$ratio decreases quickly. This trend can be explained by parasitic reactions (e.g. CO formation) in competition with carbon deposition. Temperature change has a relatively small effect on the $Q^{+} / Q^{-}$ratio.

Increasing the deposition charge has a negative effect on the $Q^{+} / Q^{-}$ratio, whilst decreasing the re-oxidation current is beneficial. This can be related to the fact that the electro-deposited carbon is composed of various nanoparticulates, instead of a dense continuum. ${ }^{11}$ Thus, carbon loss from the electrode with a thick carbon coating is highly likely during electro-oxidation, particularly considering the disturbance from $\mathrm{CO}_{2}$ bubbles leaving the electrode at high re-oxidation currents.

It was observed in some cases that the overall $Q^{+} / Q^{-}$ratio would be higher if it were higher at the end of the first re-oxidation plateau ( $c f$. Fig. 4 and Table 3 ). The first plateau corresponds to reaction (11) which produces one $\mathrm{CO}_{2}$ molecule at the expense of four electrons. At the second plateau, reaction (12) also involves four electrons, but creates three $\mathrm{CO}_{2}$ molecules. Thus, $\mathrm{CO}_{2}$ disturbance would be more significant at the second plateau than the first one, likely contributing to a greater non-electrochemical loss of carbon and hence a lower overall $Q^{+} / Q^{-}$ratio. Unfortunately, reaction (11) consumes $\mathrm{O}^{2-}$ ions supplied to the electrode surface via diffusion which limits the maximum reaction rate. On the contrary, the $\mathrm{CO}_{3}{ }^{2-}$ ion in reaction (12) is a component of the molten carbonate salt and hence cannot be depleted at the electrode surface. Thus, to promote reaction (11) and mitigate the impact from $\mathrm{CO}_{2}$ disturbance during re-oxidation (discharge), a well-balanced engineering design of the bath composition and electrode and cell structures is crucial.

\section{Prospects}

According to Fig. 4, the oxidation of carbon should ideally proceed along the lowest potential plateau for reaction (11), which requires sufficient activity of the $\mathrm{O}^{2-}$ ion. This is, however, difficult, if not impossible, to achieve in molten $\mathrm{Li}_{2} \mathrm{CO}_{3}$ or mixed $\mathrm{Li}_{2} \mathrm{CO}_{3}-\mathrm{K}_{2} \mathrm{CO}_{3}$ under a $\mathrm{CO}_{2}$ containing atmosphere. Thus, future work should include studies of carbon deposition and dissolution in molten salts with added alkali or alkaline earth metal oxides $\left(\mathrm{Li}_{2} \mathrm{O}\right.$ and $\left.\mathrm{CaO}\right)$. Apparently, at sufficiently high activities of the $\mathrm{O}^{2-}$ ion, reaction $(11)\left(E^{\mathrm{o}}=-1.488 \mathrm{~V}\right)$ may change to the reverse of reaction $(6)\left(E^{\mathrm{o}}=-1.719 \mathrm{~V}\right)$ at a more negative potential. This is desirable from the viewpoint of carbon oxidation in a battery or fuel cell. On the other hand, however, because a high $\mathrm{O}^{2-}$ activity in the molten salt does not

Table 3 The $Q^{+} / Q^{-}$ratio as a function of the carbon deposition potential ( $E$ vs. $\mathrm{Ag} / \mathrm{AgCl}$ ), deposition charge $\left(Q^{-}\right)$, and re-oxidation current (I), measured in molten $\mathrm{Li}_{2} \mathrm{CO}_{3}-\mathrm{K}_{2} \mathrm{CO}_{3}$ (62: 38 , molar ratio) at $700{ }^{\circ} \mathrm{C}$ under $\mathrm{CO}_{2}$

\begin{tabular}{lclll}
\hline$E(\mathrm{~V})$ & $Q^{-}(\mathrm{C})$ & $I(\mathrm{~mA})$ & $\begin{array}{l}Q^{+} / Q^{-}, \\
1^{\text {st }} \text { plateau }\end{array}$ & $\begin{array}{l}Q^{+} / Q^{-}, \\
2^{\text {nd }} \text { plateau }\end{array}$ \\
\hline-1.68 & 1017 & 150 & 0.26 & 0.83 \\
-1.68 & 973.6 & 300 & 0.17 & 0.48 \\
-1.68 & 1301 & 450 & 0.18 & 0.34 \\
-1.98 & 1764 & 300 & 0.16 & 0.32 \\
-2.28 & 2318 & 300 & 0.15 & 0.28
\end{tabular}


favour electro-deposition of carbon via reaction (6) (nor the reduction of $\mathrm{O}_{2}$ gas in a direct carbon fuel cell), a careful balance is needed.

In addition to energy storage through electrochemical deposition and dissolution, the process of, and products from, indirect electro-reduction of $\mathrm{CO}_{2}$ to carbon can have other applications. For example, the deposited carbon can be used directly for making the electrodes of supercapacitors, ${ }^{\mathbf{1 0}}$ or, after a proper treatment, for pollutant absorption. The process itself may be used to convert $\mathrm{CO}_{2}$ gas back to $\mathrm{O}_{2}$ gas, and hence support life in space, undersea, or in mines. It is thus worth making an estimation of the cost of the electro-deposition itself. In this work, a very high current efficiency (e.g. 95\%) has been achieved in carbonate dominated baths. However, a voltage of or higher than $4.0 \mathrm{~V}$ was found to be necessary for electrolysis in the two-electrode cell, ${ }^{11}$ which is much higher than the thermodynamically predicted voltage as shown in Table 1. A possible reason is the relatively low activity of $\mathrm{O}^{2-}$ ions in the carbonate dominated bath under $\mathrm{CO}_{2}$ that invokes reaction (5) instead of (13) as the anode reaction. Thus, it is reasonable to predict that the electrolysis voltage can be reduced to below $3.0 \mathrm{~V}$ if either $\mathrm{Li}_{2} \mathrm{O}$ or $\mathrm{CaO}$ is added to the molten salts. Nevertheless, even assuming a cell voltage of 3.0-4.0 V and a 95\% current efficiency, the energy consumption of the electrolysis can be derived as 28.2-37.6 W h per kg-C, which can be translated to a cost of less than $\$ 5$ per kgC considering a $20 \%$ margin for heating and pre- and post-processing. For comparison, the current market price for supercapacitor grade activated carbon falls in the range of \$20-40 per kg-C.

\section{Summary}

The electrochemical deposition and dissolution of carbon can be achieved in carbonate containing molten salts. The deposition becomes faster when $\mathrm{CO}_{2}$ is present in the atmosphere above the molten salts. The cathodic process is dominated by carbon deposition at high current efficiency (up to 95\%), whilst CO formation and other reactions may also occur. It was observed that carbon deposition occurs on the deposited carbon more efficiently than on a freshly prepared metal electrode. Electro-re-oxidation of the deposited carbon can be achieved with the aid of either the preferred $\mathrm{O}^{2-}$ ion, or the $\mathrm{CO}_{3}{ }^{2-}$ ion at a more positive potential. Both chronopotentiometry and cyclic voltammetry revealed a fairly high ratio of deposition and dissolution charges, but also a large difference between the carbon deposition and dissolution potentials. A brief analysis of the process suggests addition of the $\mathrm{O}^{2-}$ ion in the form of either $\mathrm{Li}_{2} \mathrm{O}$ or $\mathrm{CaO}$ to the molten salts may not only be beneficial for decreasing the electrolysis voltage by avoiding direct anodic oxidation of the $\mathrm{CO}_{3}{ }^{2-}$ ion, but also enable anodic oxidation of the deposited carbon at more negative potentials.

\section{Acknowledgements}

This research received financial support from the Royal Society (2007-2009, Brian Mercer Feasibility Award), the EPSRC (2010-2015, Doctor Training Grant, EP/ F026412/1, and EP/J000582/1), and the University of Nottingham (2011-2014, Dean of Engineering Scholarships). 


\section{Notes and references}

1 Y. K. Delimarskii, O. V. Gorodiskii and V. F. Grishchenko, Dokl. Akad. Nauk SSSR, 1964, 156, 650-651.

2 M. D. Ingram, B. Baron and G. J. Janz, Electrochim. Acta, 1966, 11, 1629-1639.

3 H. Kawamura and Y. Ito, J. Appl. Electrochem., 2000, 30, 571-574.

4 L. Massot, P. Chamelot, F. Bouyer and P. Taxil, Electrochim. Acta, 2003, 48, 465471.

5 H. Groult, B. Kaplan, F. Lantelme, S. Komaba, N. Kumagai, H. Yashiro, T. Nakajima, B. Simon and A. Barhoun, Solid State Ionics, 2006, 177, 869-875.

6 K. Le Van, H. Groult, F. Lantelme, M. Dubois, D. Avignant, A. Tressaud, S. Komaba, N. Kumagai and S. Sigrist, Electrochim. Acta, 2009, 54, 4566-4573.

7 S. Licht, B. Wang, S. Ghosh, H. Ayub, D. Jiang and J. Ganley, J. Phys. Chem. Lett., 2010, 1, 2363-2368.

8 N. J. Siambun, H. Mohamed, D. Hu, D. Jewell, Y. K. Beng and G. Z. Chen, J. Electrochem. Soc., 2011, 158, H1117-H1124.

9 Q. S. Song, Q. Xu, Y. Wang, X. J. Shang and Z. Y. Li, Thin Solid Films, 2012, 520, 6856-6863.

10 H. Yin, X. Mao, D. Tang, W. Xiao, L. Xing, H. Zhu, D. Wang and D. R. Sadoway, Energy Environ. Sci., 2013, 6, 1538-1545.

11 H. V. Ijije, C. Sun and G. Z. Chen, Carbon, 2014, 73, 163-174.

12 M. Tahir and N. S. Amin, Energy Convers. Manage., 2013, 76, 194-214.

13 HSC Chemistry 6, v. 6.12, Outotec Research Oy, 2007.

14 G. Z. Chen, A feasibility study of solar-electrochemical cells for capturing atmospheric carbon, Application for The Royal Society 2007 Brian Mercer Feasibility Award, October 2006.

15 I. A. Novoselova, N. F. Oliinyk, S. V. Volkov, A. A. Konchits, I. B. Yanchuk, V. S. Yefanov, S. P. Kolesnik and M. V. Karpets, Phys. E, 2008, 40, 2231-2237.

16 R. Barnett, K. T. Kilby and D. J. Fray, Metall. Mater. Trans. B, 2009, 40, 150-157.

17 H. Wang, N. J. Siambun, L. P. Yu and G. Z. Chen, J. Electrochem. Soc., 2012, 159, H740-H746. 